\title{
EFFECT OF SPRAYING OF THOMPSON SEEDLESS GRAPEVINES WITH HYDROGEN CYANAMIDE ON BUD BEHAVIOUR \\ Deieu, L.K. ${ }^{*}$ and R. M.F.A.El alem ** \\ * The University of Agronomic Sciences and Veterinary Medicine, Bucharest, Romania \\ ${ }^{*}$ Hort. Res. Inst., Agric. Res. Center, Kafr El-Sheikh, Egypt.
}

\begin{abstract}
Dormex at $0,2,3$ and $5 \%$ was sprayed on 1 or 7 or 14 January during two seasons 2006 and 2007 on 15 years old Thompson Seedless grapevines, planted at $2 \times 2$ meter in a loamy clay soil on three dates. The results of the two experimental seasons indicated that, the response of Thompson Seedless grapevines to (Dormex) treatments varied according to the concentration and spraying date.

Budburst percentage generally increased from the basal to distal of bud location. The percentages of budburst, time budbreak and the vegetative growth were markedly increased respectively compared to control. There beneficial results concerning an advancement in date of bud burst, an increase in the percentage of buds developed to vegetative growth and appearance of flowering. The best results were obtained by $5 \%$ hydrogen cyanamide applied on the first of January in both season.
\end{abstract}

\section{INTRODUCTION}

The area under vineyards in Egypt has been greatly expanded during the last two decades. However, a considerable part of the Egyptian vineyards, are in the newly reclaimed lands, where the production expenses are relatively high and the growers have to maximize the obtained yield. (Sourial et al. 1998).

Grape is one of the important deciduous fruit trees grown in Egypt. Great attention is payed to increase the export of table grapes. Production of early Thompson Seedless with high quality is the key to increase amount of grape exported to European markets before July $15^{\text {th }}$ according to the Egyptian - European Partenership Agreement in the year 2003 (Ereze, 1987; 1990 \& 1994).

Any cultural practices that accelerate bud break and fruit ripening are highly desirable. Due to warm autumns and winters obtaining sufficient chillingfor normal bud break often is a problem in those regions. (foot. 1987; Khalil et al.., 1988; Kubata and Miyamuk. 1992; and Dokoozlian et al.. 1995).

\section{MATERIALS AND METHODS}

The present investigation was carried out during two successive seasons of 2006 and 2007 on 15 years old Thomposon Seedless grapevines grow in a private vineyard. Vines were grown in clay soil at El Gharabya Governorate, Egypt. planted at $2 \times 2$ meters and the head traning system was used in training the vines. 
The objective of the investigation was improving and enhancing bud break by using the commercial compound H2CN2 (49\% hydrogen cyanamide) applide at different dates on bud behavior percentages of bursting and fruiting buds. One sixty two Thompson Seedless grapevines were chosen as uniform in vigour as possible for this investigation .

the chosen vines were pruned at the first week of december 2006 and 2007 in the first and second seasons, respectively to leave 60 buds per vine (20 fruiting spurs X 3 buds / spur) and the suitable replacement spure ( 2 buds each ) were left.

The present experiment was set in a complete randomized block design in a split- plot arrangement 84 concentrations $X 3$ dates of application replicated 3 times with 6 vines / replicate hydrogen cyanamide treatments were as he following:

1 . (Dormex) at $0.0 \%$ (water spraying " control ")

2. (Dormex) at $2 \%$

3 . (Dormex) at $3 \%$

4. (Dormex) at $5 \%$

Experimental Work :-

Dormex ( $49 \%$ hydrogen cyanamide) was dissolved in tap water according to the named concentrations, triton $\mathrm{B}$ was added to the spraying solution at a concentration of $0.2 \%$ a wetting agent. The vines werte sprayed with the solution till runoff ( about $2-3$ liters per vine) at the prementioned spraying dates ( 1,7 \& 14 Jan. each season).

All vines received the regular agricultural and horticultural practices applied in the vineyard except those included in the experimental work .

\section{Bud behaviour and percentages of bursted and fruiting buds measurements :-}

Observations on bud behaviour were carried out at weekly intervals during the period started one week after each Dormex spraying date and ended at the first week of May in 2006 and 2007. The number of bursted and fruiting buds were recorded for each interval, then the additive number along the observation period was recorded to calculate the percentage of both in relative to the total number of buds left per vine.

165 The percentage of bud burst was calculated according to the following equation .

$$
\text { Bud burst } \%=\frac{\text { Number of bursted buds }}{\text { Total number of buds left per vine }}
$$

166 The percentage of Fruiting buds was calculated according to the following wquation :

$$
\text { Fruiting buds } \%=\frac{\text { Number of fruiting buds }}{\text { Total number of buds left per vine }}
$$

Also, the number of days from pruning till the start of buds break ( green point ), from pruning to the appearance of the first cluster and that from the start of bud break till the appearance of the first cluster were recorded. 


\section{RESULTS AND DISCUSSION}

\section{Bud behaviour:}

\section{1- percentage of budbreak}

Data in table (1) Showed that the bud break of Thompson Seedless grapevines was significantly increased by the application of H2CN2 by 5,3 \& $2 \%$ at $1,7 \& 14$ January respectively, ...

Compared to the control $(0.0 \%)$ treatment. This observation was true either the trend or the statistical provement are concerned. Furthermore, the results were similar in the second experimental.

It could be revealed that the detected effect of hydrogen cyanamide treatment on the percentage of fruiting buds was a direct result for the effect of $\mathrm{H} 2 \mathrm{CN} 2$ treatment on the percentage of budbreak. In other words, it could be said that the effect of the treatments in increasing the total number of budbreak accordingly their percentage was relative to the total of buds left on the vine as a direct effect of the treatments on budbreak. Such results are in agreement with those reported by Ayaad (1992), Abbas et al. (1999) and Omran et al.. (2005) on Thompson Seedless grapevine

Table (1.a): Effect of hydrogen cyanamide on percentage of budbreak of Thompson Seedless grapevine during 2006 season.

\begin{tabular}{|c|c|c|c|c|c|c|c|c|}
\hline \multirow{2}{*}{$\begin{array}{c}\text { Date of } \\
\text { spraying }\end{array}$} & \multirow{2}{*}{$\begin{array}{l}\text { Dormex } \\
\text { Conc.\% }\end{array}$} & \multicolumn{7}{|c|}{ Bursted buds } \\
\hline & & $15 / 2$ & $22 / 2$ & $1 / 3$ & $8 / 3$ & $15 / 3$ & $22 / 3$ & $29 / 3$ \\
\hline \multirow{6}{*}{ 1/1/2006 } & 0 & - & - & - & - & 18.9 & 38.4 & 61.2 \\
\hline & 2 & - & 1.4 & 5.6 & 34.8 & 71.1 & - & - \\
\hline & 3 & - & 1.9 & 7.1 & $42.4^{b}$ & 73.8 & - & - \\
\hline & 5 & 1.2 & 6.7 & 11.7 & 64.1 & 81.3 & - & - \\
\hline & $\mathrm{F}=$ & 0.0 & $30.2^{* *}$ & $52.16^{\star *}$ & $41.57^{* *}$ & $33.18^{* *}$ & 0.0 & 0.0 \\
\hline & LSD 0.05= & - & 0.50 & \begin{tabular}{|l|}
1.44 \\
\end{tabular} & \begin{tabular}{|l|}
10.57 \\
\end{tabular} & 2.57 & - & - \\
\hline \multirow{6}{*}{ 7/1/2006 } & 0 & - & - & - & - & 16.5 & 35.7 & 57.8 \\
\hline & 2 & - & 1.2 & 5.3 & 32.6 & 70.9 & - & - \\
\hline & 3 & - & 1.7 & 6.8 & 39.7 & 72.6 & - & - \\
\hline & 5 & 1.1 & 6.1 & 10.9 & 63.5 & 80.7 & - & - \\
\hline & $\mathrm{F}=$ & 0.0 & $22.47^{\star *}$ & $15.78^{\star \star}$ & $41.58^{\star *}$ & $33.71^{* *}$ & 0.0 & 0.0 \\
\hline & LSD $0.05=$ & - & 0.51 & \begin{tabular}{|l|}
2.78 \\
\end{tabular} & \begin{tabular}{|l|}
7.48 \\
\end{tabular} & 1.94 & - & - \\
\hline \multirow{6}{*}{ 14/1/2006 } & \begin{tabular}{|l|}
0 \\
\end{tabular} & - & - & - & - & 16.5 & 35.7 & 57.8 \\
\hline & 2 & - & 1.0 & 4.9 & 31.8 & 69.8 & - & - \\
\hline & 3 & - & 1.6 & 6.3 & 35.4 & 71.4 & - & - \\
\hline & 5 & 0.9 & 5.8 & 10.0 & 62.3 & 80.2 & - & - \\
\hline & $\mathrm{F}=$ & 0.0 & $35.78^{*}$ & $22.48^{*}$ & $35.47^{\star \star}$ & $19.76^{\star}$ & 0.0 & 0.0 \\
\hline & LSD 0.05= & 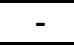 & 0.60 & 1.98 & 4.15 & 2.79 & & \\
\hline
\end{tabular}


Table (1.b): Effect of hydrogen cyanamide on percentage of budbreak of Thompson Seedless grapevine during 2007 season.

\begin{tabular}{|c|c|c|c|c|c|c|c|c|}
\hline \multirow{2}{*}{$\begin{array}{c}\text { Date of } \\
\text { spraying }\end{array}$} & \multirow{2}{*}{$\begin{array}{l}\text { Dormex } \\
\text { Conc.\% }\end{array}$} & \multicolumn{7}{|c|}{ Number of bursted buds } \\
\hline & & $15 / 2$ & $22 / 2$ & $1 / 3$ & $8 / 3$ & $15 / 3$ & $22 / 3$ & $29 / 3$ \\
\hline \multirow{6}{*}{$1 / 1 / 2007$} & 0 & - & - & - & - & 15.4 & 32.5 & 58.7 \\
\hline & 2 & - & 1.2 & 5.1 & 30.4 & 69.7 & - & - \\
\hline & 3 & - & 1.5 & 6.8 & 37.9 & 72.4 & - & - \\
\hline & 5 & 1.0 & 6.1 & 10.3 & 59.2 & 77.6 & - & - \\
\hline & $\mathrm{F}=$ & 0.0 & $42.89^{\star \star}$ & $35.45^{*}$ & $44.77^{*}$ & $19.18^{*}$ & 0.0 & 0.0 \\
\hline & LSD $0.05=$ & - & 0.30 & 1.72 & 6.89 & 4.59 & - & - \\
\hline \multirow{6}{*}{$7 / 1 / 2007$} & 0 & - & - & - & - & 15.9 & 31.2 & 54.3 \\
\hline & 2 & - & 1.1 & 4.9 & 27.6 & 68.5 & - & - \\
\hline & 3 & - & 1.4 & 6.2 & 33.7 & 70.2 & - & - \\
\hline & 5 & 0.9 & 5.9 & 9.3 & 60.2 & 77.0 & - & - \\
\hline & $\mathrm{F}=$ & 0.0 & $19.76^{\star \star}$ & $20.15^{\star}$ & $31.89^{* *}$ & $24.58^{*}$ & 0.0 & 0.0 \\
\hline & LSD $0.05=$ & - & 0.30 & 2.78 & 3.79 & 2.30 & - & - \\
\hline \multirow{6}{*}{$14 / 1 / 2007$} & 0 & - & - & - & - & 17.9 & 32.9 & 55.4 \\
\hline & 2 & - & 8.0 & 3.6 & 29.8 & 65.7 & - & - \\
\hline & 3 & - & 1.4 & 6.0 & 31.9 & 69.9 & - & - \\
\hline & 5 & 0.8 & 5.3 & 9.1 & 60.1 & 76.5 & - & - \\
\hline & $\mathrm{F}=$ & 0.0 & $22.97^{*}$ & $54.12^{\star *}$ & $18.74^{\star *}$ & $17.48^{*}$ & 0.0 & 0.0 \\
\hline & LSD $0.05=$ & - & 3.79 & 2.97 & 2.88 & 4.81 & - & - \\
\hline
\end{tabular}

\section{2- Date of appearance first flowering cluster}

It is seen from table (2) that all (Dormex) concentrations enhanced flower bud break especially the treatments which began earlier. Hydrogen cyanamide concentration ranged from 2 to $5 \%$ greatly reduced the periods for flower appearance compared to spraying with tap water ( $0.0 \%$ Dormex ) in the two experimental seasons.

The results also showed that, hydrogen cyanamide is very effective in this concern since bud break in Thompson Seedless grapevines was advanced and the appearance of clusters became earlier due to spraying this compound on the vines. This could be due to its mechanical effect on bud scales in addition to its previously mentioned effect in improving the nutritional stasus in the vine.

\section{Days after pruning}

Data in Table (2) showed that spraying (Dormex) after pruning caused a decrease in number of days to flower appearance in all treatments compared to control. During the first season all treatments of 2, $3 \& 5 \%$ significantly decreased days after pruning than in the second season of study.

The graduation of data days after pruning caused a decrease in number of days in all treatments compared to control. During the second seasons all treatments of 2,3 \& $5 \%$ significantly decreased days after pruning than control in the second seasons of study.

\section{Gained earliness (days)}

It could be indicated that the effect of the used concentrations of (Dormex), decreased the number of days in first and second season 
concentration from $5,3,2 \%$ at 1,7 and 14 January respectively compared to control.

The data are in line with Sourial et al.. (1993), Rizk (1996), Abbas et al.. (1999) and El- Shazily (1999) on Thompson Seedless grapevine, ElSayed et al. (2002) on Inred Roomy vines.

Table (2): Effect of hydrogen cyanamide on days after pruning, gained and appearance of flowering of Thompson Seedless grapevine during 2006 and 2007 seasons.

\begin{tabular}{|c|c|c|c|c|}
\hline $\begin{array}{c}\text { Date of } \\
\text { spraying }\end{array}$ & $\begin{array}{c}\text { Dormex } \\
\text { conc. (\%) }\end{array}$ & $\begin{array}{c}\text { Days after } \\
\text { pruning }\end{array}$ & $\begin{array}{c}\text { Gained earliness } \\
\text { (days) }\end{array}$ & $\begin{array}{c}\text { appearance } \\
\text { of flowering }\end{array}$ \\
\hline Season 2006 & 0 & 54 & - & 104 \\
Jan., 1 & 2 & 37 & 16 & 86 \\
& 3 & 42 & 11 & 88 \\
& 5 & 47 & 7 & 92 \\
\hline & 2 & 32 & 21 & 85 \\
Jan., 7 & 3 & 36 & 17 & 87 \\
& 5 & 41 & 10 & 91 \\
\hline & 2 & 31 & 22 & 84 \\
Jan., 14 & 3 & 34 & 18 & 87 \\
& 5 & 37 & 15 & 91 \\
& F & 15.48 & 16.59 & 21.58 \\
& LSD & 4.45 & 4.51 & 8.47 \\
\hline Season 2007 & 0 & 59 & - & 107 \\
Jan., 1 & 2 & 40 & 14 & 91 \\
& 3 & 45 & 9 & 95 \\
& 5 & 48 & 6 & 98 \\
\hline \multirow{3}{*}{ Jan., 7 } & 2 & 38 & 16 & 90 \\
& 3 & 41 & 13 & 92 \\
& 5 & 45 & 9 & 95 \\
\hline \multirow{3}{*}{ Jan., 14 } & 2 & 34 & 20 & 86 \\
& 3 & 37 & 17 & 87 \\
& 5 & 40 & 14 & 90 \\
& F $=$ & 11.58 & 12.39 & 33.18 \\
& LSD & 3.22 & 3.48 & 6.47 \\
\hline
\end{tabular}

\section{REFERENCES}

Abbas, M.T.; A.M. Melook and U.K.EL-Abassy (1999). Effect of some chemical treatments during dourment season on growth and fruiting of Thompson Seedless grapevine. Bull. Fac. Agric., Cairo Univ, Egypt. Res. 50(1999):558-574.

Abd-Elghany, A.A.; Mostafa,R.A.A. and A. M. A. El-Sese. (2001). Influence of hydrogen cyanamide and ammonium sulfate fertilizer on budbreak and fruit quality of Thompson Seedless grapes. Fac. Agric. Sci. Mansoura Univ., 26 (4): 2217- 2221, 2001.

Ayaad, H. M. (1992). Effect of hydrogen cyanamide (dormex) and Kno3 on bud break, fruit qoality and yield of Thompson Seedless grapevines Tanta Univ, Egypt. J. Agric. Res. 18(1) 171-181. 
El-Sayed.H.A,M.M.Shoaieb and M.M.EL-Mogy(2002). Acomparative study on some substances used inbreaking dormancy in Red Roomy vines. Minia. J. Agric, Egypt. Res. 1(22):115-127

El-Shazly.S.M. (1999). Effect of hydrogen cyanamide (Dormex) spray on bud brhaviour, growth, yield, fruit quality and leaf mineral composition of Thompson Seedless grapevines. Alex. J. Agric, Egypt. Rec. 44 (2): 221-235.

Omar.A.H. and V.H. Girgis (2004). Early and Low-cost production of exportable Thompson Seedless table grapes. Minia. J. Of Agric, Egypt. Res. 1(24) $89-102$.

Rizk. I. A. (1996). Chemical constituents of thompson seedless grape buds as affected by hydrogen cyanamide treatment. Bull. Fac. Agric., Cairo Univ, Egypt. 47: $273-294$.

Shehata, M.M. (1996). Forcing uniformbud break in early maturigg Flame Seedless table grapes grown in Egypt by some budbreaking agents. Alex, Egypt. J. Agric. Res. 41(2): 313 - 322.

Sourial, G.F.; Al- Ashkar, R.A. ; Safaa, A. Nomier and Mahmoud, Z.E. (1998). Flame Seedless grapevines produce two crops in the same year in response to late summer defoliation, pruning and hydrogen cyanamide treatments. 2. Bud behaviour and vegetative growth. Zagazig, Egypt. J. Agric. Res. 25 (3): 457-475.

Sourial, G.F.; Atteyat S. Abd El - Aziz, M.H. El-Kholi; S.M. El-Hefnawy and M.M. Banoub (1994). Response of Sultani fig trees to some hydrogen cyanamide treatments during the dormant season. 1. Bud Behaviour. Zagazing, Egypt. J.Agric. Res. 21 (2): $439-453$.

Sourial, G.F.; Atteyat S. Abd El - Aziz, M.H. El-Kholi; S.M. El-Hefnawy and M.M. Banoub (1994). Response of Sultani fig trees to some hydrogen cyanamide treatments during the dormant season. Vegetative Growth. Zagazing, Egypt. J.Agric. Res. 21 (2): 455-465.

Sourial, G.F.; R.A. Al-Ashkar, Safaa A. Nomier and Z.E. Mahmoud (1998). Flme Seedless grapevines produce two crops in the same year in response to late summer defoliation, pruning and hydrogen cyanamide treatments. 1. yield and fruit quality. Zagazig, Egypt. J. Agric. Res. 25(3): $437-455$.

Sourial, G.F.; M.H. Elkholi; Atteyat S. Abdel - Aziz; Faiz G. Nakhlla and Esam A. Lotfy (1993). Response of Banaty grapevines to some hydrogen cyanamide treatments. 1- Time of budburst, Flowering and berry ripening. Zagazig, Egypt. J. Agric. Res. 20(3) 1141 -1152.

Sourial, G.F.; M. H. Elkholi; Atteyat S. Abdel - Aziz; Faiz G. Nakhlla and Esam A. Lotfy (1993). Zagazig, Egypt. J. Agric. Res . 20 (3). 1153 1162.

Sourial. G. F. , R.A. Al- Ashkar, Safaa A. Nomier and Z.E. Mahmoud (1998). Flame Seedless grapevines produce two crops in the same year in response to late summer defoliation, pruning and hydrogen cyanamide treatments. Bud behaviour and vegetative growth. Zagazig, Egypt. J. Agric. Res. 25(3). 
Stino, R.G. and E.El-Fakharani (1995). Fruting of Conadria Fig trees as affected by type of pruning and hydrogen cyanamide application. Fac. Agric., Cairo Univ,Egypt. J. Hort. 22, pp. 193-211 (1995).

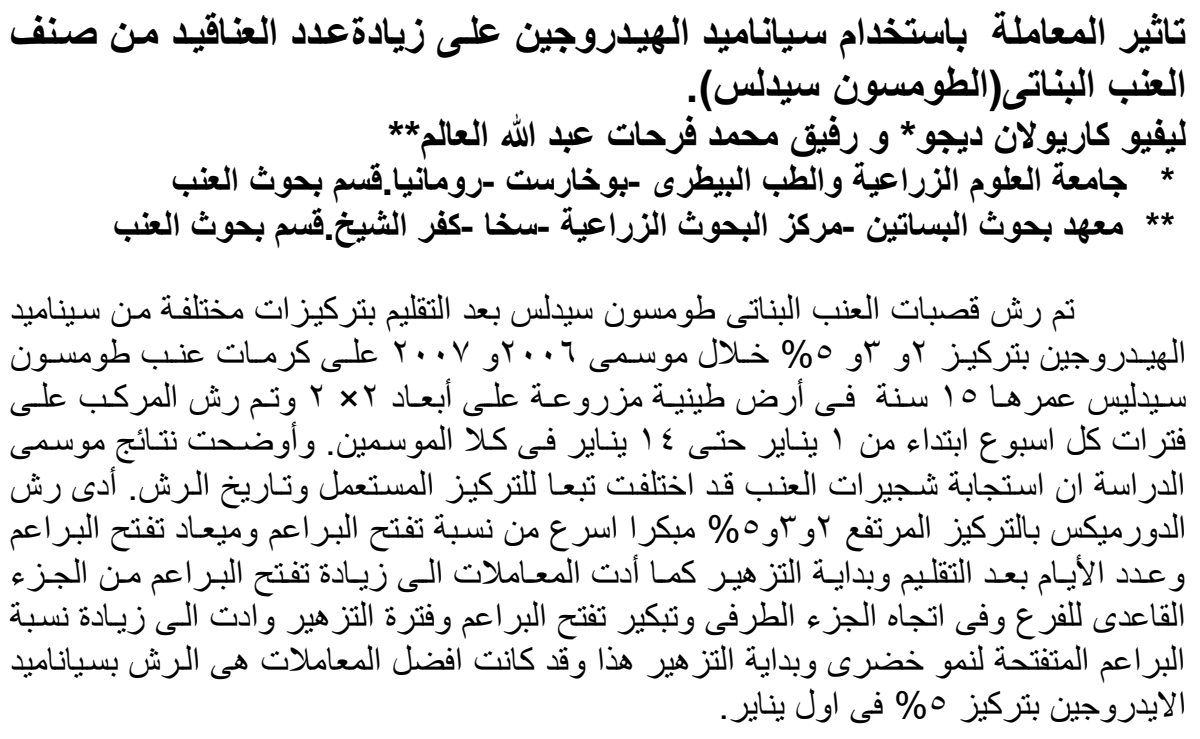

